\title{
Effect of Supplementation of Dried Bioflocs Produced by Freeze-Drying and Oven-Drying Methods on Water Quality, Growth Performance and Proximate Composition of Red Hybrid Tilapia
}

\author{
Tarq Binalshikh-Abubkr ${ }^{1,2}$ and Marlia Mohd Hanafiah 1,3,* \\ 1 Department of Earth Sciences and Environment, Faculty of Science and Technology, Universiti Kebangsaan \\ Malaysia, Bangi 43600, Malaysia; p93366@siswa.ukm.edu.my \\ 2 Department of Food Science and Technology, Faculty of Environmental Science and Marine Biology, \\ Hadhramout University, Mukalla P.O. Box 50512, Yemen \\ 3 Centre for Tropical Climate Change System, Institute of Climate Change, Universiti Kebangsaan Malaysia, \\ Bangi 43600, Malaysia \\ * Correspondence: mhmarlia@ukm.edu.my
}

Citation: Binalshikh-Abubkr, T.; Mohd Hanafiah, M. Effect of Supplementation of Dried Bioflocs Produced by Freeze-Drying and Oven-Drying Methods on Water Quality, Growth Performance and Proximate Composition of Red Hybrid Tilapia. J. Mar. Sci. Eng. 2022, 10, 61. https://doi.org/10.3390/ jmse10010061

Academic Editor:

Dariusz Kucharczyk

Received: 2 November 2021 Accepted: 14 December 2021 Published: 5 January 2022

Publisher's Note: MDPI stays neutral with regard to jurisdictional claims in published maps and institutional affiliations.

Copyright: (c) 2022 by the authors. Licensee MDPI, Basel, Switzerland. This article is an open access article distributed under the terms and conditions of the Creative Commons Attribution (CC BY) license (https:// creativecommons.org/licenses/by/ $4.0 /)$

\begin{abstract}
Supplementation of dried bioflocs for red hybrid tilapia (Oreochromis sp.) was examined during 57 days of feeding trials. Five experimental treatments; T1 (the control; without bioflocs), T2 (4\% freeze-dried bioflocs), T3 (16\% freeze-dried bioflocs), T4 (4\% oven-dried bioflocs), and T5 (16\% oven-dried bioflocs) were prepared to examine the water quality, growth performance and body composition of red hybrid tilapia. T2 and T4 treatments resulted in a higher growth rate and survival similar to the control, while T3 and T5 treatments showed the lowest values of growth performance among all treatments. $\mathrm{T} 1$ treatment showed the best quality of culture water followed by $\mathrm{T} 2$ and $\mathrm{T} 4$ treatments, while T3 treatment resulted in poor water quality followed by T5 treatment. Based on these results, the ratios of bioflocs ( $4 \%$ and $16 \%$ ) had more effect on fish growth and water quality than the drying methods (freeze-drying and oven-drying). The ratio of $4 \%$ freeze-dried or oven-dried bioflocs provided higher growth rates and better water quality parameters similar to the control, while the ratio of $16 \%$ showed the worst growth performance and water quality in the present study. In addition, body compositions of tilapia fed $4 \%$ dried bioflocs showed better nutritional value than tilapia fed $16 \%$ dried bioflocs. Protein and energy levels showed an increasing trend with decreasing supplement levels of bioflocs. Moisture content was significantly higher when supplementation of $16 \%$ bioflocs was used. Overall, supplementation of $4 \%$ freeze-dried or oven-dried bioflocs can be successively included in red hybrid tilapia diets without any effects on growth or body composition and can result in a good quality of culture water for red hybrid tilapia.
\end{abstract}

Keywords: biofloc technology; red hybrid tilapia; water quality; growth performance; proximate composition

\section{Introduction}

In the recent past, feed expenses have become an urgent issue for the aquaculture sector because of the high cost of feed ingredients and the continually increasing of using of animal or plant origin (such as fishmeal and soybean meal) as a protein source in aquafeeds to meet nutritional requirements for fish feed [1,2]. About $50 \%$ of operating cost comes only from fish feeding [3]. Therefore, to maximize the benefit and to achieve the sustainable goals of this industry, other alternatives, more economic protein sources, are needed to be used as a replacement for the partial or even total traditional ingredients in the formulation of diets $[4,5]$.

Recently, the use of several microbial biomasses as sources of protein has garnered more attention from researchers [6-9]. Among these, microbial flocs which are also known 
as bioflocs are widely used for culture animals and highly recommended to enhance production through the provision of natural food in situ [10]. Bioflocs can be collected from biofloc technology (BFT) system as a wet meal to culture animals $[11,12]$ or as a dried meal after drying processes with high protein levels [13-15]. BFT system has many benefits to increase the profitability of the aquaculture industry and also support the sustainability of this sector [16]. In that sense, BFT can keep land and water resources used for fish farming and reduce the environmental impact of aquaculture activities on external water bodies [17-19]. Moreover, bioflocs meal is considered as a high-quality resource of protein, as a result of a high level of protein in muscles of fish [20]. The technology as well as the use of bioflocs meal as a supplement or replacement of a part of expensive feed ingredients (fish meal and fish oil) is very promising to minimize feed costs and maximize farm profits.

Bioflocs can be successfully consumed by herbivorous and omnivorous fish species [16] Fish consumption of bioflocs depends on various factors such as the feeding habit of the species and its ability to eat the flakes and suspended particles density [21]. Due to its omnivorous habit, tilapia can use bioflocs as a food source, and bioflocs can meet up to $50 \%$ of the protein requirements of fish [22]. Tilapia is one of the potential fish species that can be cultured in freshwater and saline water and can tolerate a wide range of water salinity [23]. However, this ability is mainly dependent on tilapia species. For example, hybrid species of tilapia that descended from salt-tolerant parents are highly salinity tolerant [24]. Red hybrid tilapia can grow better in brackish water tanks under a bioflocs system [25]. Commercially, the fish become one of the export commodities due to the continually increasing acceptance and consumption rate of this type of fish $[24,26]$.

The development of the aquaculture sector and the increase of fish production require information on the effect of feed ingredients, environmental conditions, and other factors in culture tanks on the growth of fish [27]. Not only the growth but also water quality can be affected by those factors [28]. For example, inedible parts of the feed, metabolic waste products, and faces of fish will accumulate in the culture tank, decompose, and decrease water quality parameters resulting in stressing the fish and production decrease [25]. Therefore, water quality parameters are the key factor that can limit the increase in the production of fish farming and need to be managed properly for an optimal standard of water quality for cultured animals [29].

Additionally, the nutritional value of the final product is also an important issue. Consumers prefer high-quality, safe, and more nutritious food products. Growth studies of cultured animals often rely on the proximate composition of experimental diets [12,30], and fish composition. Knowledge of the proximate composition of fish and factors affecting that composition allows us to determine the nutrient transfer efficiency from the feed to the fish body, and to assess fish health, and also makes it possible to probably modify the composition of the final product [31]. Thus, the whole-body composition can play an important role in improving the efficiency of formulated diets, reducing overall feed waste, and increasing the profitability of the culture operation [31]. The changes in body composition of tilapia fish have been determined by numerous researchers, especially at the end of their experiments (final fish), however, there is a lack of information on the proximate composition of the carcass of fish (initial fish) at the beginning of their fish feeding experiment [31-36].

Even though bioflocs meal is considered as a high-quality resource of protein [20] and provided higher profit of farmed fish if it applied as a replacement of commercial feed or served as a protein source in diets [15], novel methods for integrating bioflocs with the aquaculture feeding is required to maximize nutrient recovery and minimize using of animal/plant protein sources in feed $[13,37,38]$.

Therefore, to investigate the efficiency of bioflocs as a dietary supplement to enhance growth, water quality, and body composition of red hybrid tilapia reared in brackish water (10 ppt), two different dried bioflocs (freeze-dried and oven-dried) were evaluated in two different ratios ( $4 \%$ and $16 \%$ ) and were compared to a control without bioflocs in five experimental diets. 


\section{Materials and Methods}

\subsection{Raw Materials}

\subsubsection{Bioflocs Sampling}

In this study, three indoor red hybrid tilapia bioflocs system tanks at a commercial farm located in Sepang, Selangor, Malaysia were used for bioflocs sampling. Bioflocs samples were collected by using a $40 \mu \mathrm{m}$ plankton net then transported to the laboratory at the Universiti Kebangsaan Malaysia (UKM), Selangor, Malaysia. The collected bioflocs were divided into two parts; the first part was frozen immediately at $-80{ }^{\circ} \mathrm{C}$ for two days then freeze-dried at a vacuum freeze-dryer for three days. The second part was dried in an oven at $40{ }^{\circ} \mathrm{C}$ for three days. After that, the freeze-dried and oven-dried bioflocs were kept in zip-lock plastic bags and stored in a refrigerator at $4{ }^{\circ} \mathrm{C}$ for proximate and experimental diets analysis.

\subsubsection{Red Hybrid Tilapia Fingerlings}

Red hybrid tilapia fingerlings were purchased from a commercial fish farm located in Kuala Selangor, 42300 Selangor, Malaysia. The fish were transported in specific plastic bags with oxygen to the laboratory (UKM). The bags including fish were dived into the aquarium water for $20 \mathrm{~min}$ to balance the water temperature. Then the fish were allowed to move slowly into the aquarium. The fish were not fed for $24 \mathrm{~h}$ to avoid any shock.

\subsection{Experimental Diets}

Five experimental diets; T1, as a control diet, (100\% commercial feed) without bioflocs, T2 (4\% freeze-dried bioflocs), T3 (16\% freeze-dried bioflocs), T4 (4\% oven-dried bioflocs), and T5 (16\% oven-dried bioflocs) were prepared to be examined for growth and water quality of red hybrid tilapia. All the dried ingredients were mixed with warm water to make dough. The dough was pressed through a manual pelletizer for homogeneous and then dried in an oven at $60^{\circ} \mathrm{C}$ for $72 \mathrm{~h}$. The dried diet was crushed to less than $2 \mathrm{~mm}$ size, then stored at $4{ }^{\circ} \mathrm{C}$ till use.

\subsection{Experimental Design and Feeding Trail}

The experiment was conducted at the marine laboratory of Earth Sciences and Environment Department, Faculty of Science and Technology, UKM, Bangi, Selangor, Malaysia. An experimental design of 10 glass tanks $(64.5 \times 37 \times 38)$ with an approximate capacity of 90.5 L was used to rear the fingerlings of red hybrid tilapia. The tanks were provided with oxygen using a large air pump through a net of plastic pipes. Each tank was designed with an individual biology filter $(1 / 6$ of the tank size) and a small water pump (power $580 \mathrm{~L} / \mathrm{h}$ ).

Before the start-up of the experiment, the fish were acclimated to the new environmental conditions at a laboratory for a week. During the acclimation period, the fish were fed with a commercial feed in a proximate composition of $12 \%$ moisture, $15 \%$ ash, $34 \%$ protein, $6 \%$ fat, and $7 \%$ fiber as provided by the manufacturing (Red Eagle brand, Sri Edaran Hong Enterprise, Kelantan, Malaysia). After the acclimation period, 150 fishes were selected with an average weight of $4 \pm 0.068 \mathrm{~g}$ and distributed randomly in 10 experimental tanks (five fish groups in duplicate) with a stocking density of 15 fingerlings per tank for eight weeks (57 days). Fish were fed three times per day at 10.00 a.m., 1.00 p.m., and 4.00 p.m. with a feeding ratio of $10 \%$ of fish biomass weight per tank [39]. The feeding ratio was constantly adjusted throughout the rearing period and reduced to $8 \%$ or $5 \%$ depending on the weekly fish biomass gain $[35,36,40]$. Uneaten feed was siphoned and filtered for further calculations.

A quarter of water was exchanged and the filter wool with fish wastes was removed from the primary stage of the biology filter and replaced with a new one for every week in each tank. After water exchange, the salinity of 10 ppt was maintained at all experimental tanks by adding commercial marine salt (Aquarium Systems Instant Ocean, bucket of $25 \mathrm{~kg}$, Aquarium Systems, Sarrebourg, France). The reason for using $10 \mathrm{ppt}$ salinity is because that is the salinity of saline water, especially brackish water between 8 ppt [41] and 
10 ppt [35], which is recommended to improve the growth of the fish. Furthermore, studies of bioflocs supplementations for red hybrid tilapia reared in salinized water are limited. Therefore, a salinity of 10 ppt was set to all experimental tanks.

A sample of seven fish per tank was randomly collected in the beginning and also every week throughout the experimental duration. From this fish sample, individual fingerlings were measured to obtain the weight to the nearest $0.0001 \mathrm{~g}$ and the length using the laboratory fish measuring board to the nearest $0.1 \mathrm{~mm}$, as well as to adjust the feed amount.

\subsection{Growth Performance}

Fish performance was evaluated by body weight gain (WG; g), specific growth rate (SGR \%), feed intake per fish (FI; g), feed conversion ratio (FCR), feed efficiency ratio (FER), the protein efficiency ratio (PER) and survival rate (SR). These parameters were measured using equations mentioned by Lopez-Betancur et al. [36] as follows:

$$
\begin{gathered}
\text { WG }(\mathrm{g})=\text { Final weight }(\mathrm{g})-\text { Initial weight }(\mathrm{g}) \\
\text { SGR }(\%)=\frac{\text { Ln final weight }- \text { Ln initial weight }}{\text { days }} \times 100 \\
\text { FI }(\mathrm{g})=\frac{\text { total feed consumption per tank }}{\text { Number of fish per tank }} \\
\text { FCR }=\frac{\text { Feed intake }(\mathrm{g})}{\text { Gain in fish weight }(\mathrm{g})} \\
\text { PER }=\frac{\text { Gain in fish weight }(\mathrm{g})}{\text { Protein intake }(\mathrm{g})} \\
\text { SR }(\%)=\frac{1}{\text { Total number of fish survival }} \\
\text { Total number of fish stocked }
\end{gathered}
$$

\subsection{Water Quality Parameters}

Water quality parameters were measured in triplicate. Parameters such as dissolved oxygen (DO), temperature, salinity, conductivity (EC), total dissolved solids (TDS), and $\mathrm{pH}$ were measured daily in the tanks of fish. A handheld multiparameter water quality instrument (EcoSense ${ }^{\circledR}$-EC300A, YSI Inc., Yellow Springs, OH, USA) was used for temperature, salinity, EC, and TDS measurements. DO was monitored continuously by a dissolved oxygen meter (YSI 5000) and a pH meter (LAQUA PH1100, HORIBA Advanced Techno, Co., Ltd., Fukuoka, Japan) was used for $\mathrm{pH}$ measurement. A water sample of $500 \mathrm{~mL}$ was collected every week from each tank and filtered through dried and weighed Whatman 1822-047 GF /C filter paper under vacuum pressure and used for total suspended solids (TSS) measurement (Eaton et al., 2005). Then the filtered water samples were used for total ammonia-nitrogen (TAN), nitrate-nitrogen $\left(\mathrm{NO}_{3}-\mathrm{N}\right)$, phosphate $\left(\mathrm{PO}_{4}{ }^{-}\right)$, and chemical oxygen demand (COD) measurements according to the standard method [42]. Biological oxygen demand (BOD) was also measured every week using a five-day BOD $\left(\mathrm{BOD}_{5}\right)$ test [43].

\subsection{Proximate Composition}

Moisture, ash, protein, lipid, and fiber contents of the bioflocs and experimental diets were analyzed using the standard method of AOAC [44], where all samples were analyzed in triplicate. For moisture measurement, known grams of the sample were pre-weighed (W1) on a crucible and placed in a vacuum oven at $105^{\circ} \mathrm{C}$ for $24 \mathrm{~h}$. The sample was 
removed from the oven, cooled in a desiccator, and re-weighed (W2). Moisture percentage was calculated according to the formula:

$$
\text { Moisture }(\%)=\frac{\mathrm{W} 1-\mathrm{W} 2}{\mathrm{~W} 1} \times 100
$$

A porcelain crucible with a dry sample from the moisture analysis was used for the total ash measurement incinerated in a muffle oven at $550{ }^{\circ} \mathrm{C}$ for $4 \mathrm{~h}$. The crucible was removed from the muffle oven, cooled in a desiccator, and then weighed. Ash content was calculated according to the following formula:

$$
\text { Total ash }(\%)=\frac{\text { ash weight }}{\text { sample weight }} \times 100
$$

Protein content was determined using the Kjeldahl procedure which is basically divided into three parts: (1) digestion, (2) distillation, and (3) titration. The procedure used in this work measures the protein percentage as a nitrogen content of the dried sample. The protein content then was calculated assuming a ratio of protein to nitrogen for the specific food being analyzed $(\mathrm{N} \times 6.25)$. Lipid content was determined by a system of fat extraction (Soxtec ${ }^{\mathrm{TM}}$ 2043, FOSS, Denmark), and the lipid percentage was calculated according to the following formula:

$$
\text { Crude lipid }(\%)=\frac{\text { corrected weight of fat }}{\text { sample weight }} \times 100
$$

Fiber content was determined using a fiber analyzer (FiberCap ${ }^{\mathrm{TM}}$ 2022, FOSS, Hillerød, Denmark). In this procedure, digestible carbohydrates, lipids, and proteins are selectively solubilized by chemicals $\left(\mathrm{H}_{2} \mathrm{SO}_{4}\right.$ and $\left.\mathrm{NaOH}\right)$. Then, undigested materials are collected by filtration, and the fiber residue was recovered, dried, and weighed. After that preweighed, insoluble residue was ashed for correcting any mineral contamination of the crude fiber content.

Organic matter (OM), nitrogen-free extraction (NFE), and gross energy were calculated using the formulas described by Shyne Anand et al. (2014):

$$
\mathrm{OM}=100-\text { total ash }
$$

NFE $(\%)=100-($ moisture + total ash + crude protein + crude lipid + crude fiber $)$

$$
\begin{aligned}
& \text { Gross energy }\left(\frac{\mathrm{Kcal}}{100 \mathrm{~g}}\right) \\
& =(\text { crude protein } \times 5.6)+(\text { crude lipid } \times 9.44) \\
& + \text { crude fiber } \times 4.1)+(\mathrm{NFE} \times 4.1)
\end{aligned}
$$

The composition of the whole body of experimental fishes (initial and final measurements) was analyzed using methods similar to those described above. A group of fish was sacrificed and minced using a blender (model; Panasonic MX-GM1011), and representative subsamples were taken of each treatment and dried in an oven at $105{ }^{\circ} \mathrm{C}$ for $24 \mathrm{~h}$, then mortar was used to ground and pestle for proximate analysis (Long et al., 2015). For the convenience of calculation, protein, lipid, and crude fiber contents were determined on a dry weight basis and then converted on a wet weight basis.

\subsection{Data Analysis}

Statistical analysis was performed using the statistical package SPSS version 22. First of all, Kolmogorov-Smirnov test for normality and Levene's test for homogeneity was used for variances. After the normality and homogeneity were met, means of the experimental treatments were compared using analysis of variance test (ANOVA), and treatments were considered as independent variables (factors), and parameters of growth, water quality, and proximate composition were considered as dependent variables (measured variables). 
Significant differences among the means were determined using one-way ANOVA followed by a Tukey test at a 95\% confidence interval $(p<0.05)$. Descriptive statistics were done individually for each treatment to show maximum and minimum values for water quality variables.

\section{Results}

Table 1 shows the one-way ANOVA test for the effect of experimental diets on the growth performance of red hybrid tilapia. The Kolmogorov-Smirnov test (normality of variance test) for the five groups of treatments indicated that the data came from a normal distribution, and the Levene's test (Homogeneity of variance test) indicated that the data were homogeneous variance among all groups of data. Treatments: T1 ( $0 \%$ bioflocs), T2 ( $4 \%$ freeze-dried bioflocs), T3 (16\% freeze-dried bioflocs), T4 (4\% oven-dried bioflocs) and T5 (16\% oven-dried bioflocs) were considered as factors for ANOVA.

Table 1. The effect of experimental diets of dried bioflocs on the growth performance of red hybrid tilapia.

\begin{tabular}{cccccc}
\hline \multirow{2}{*}{ Growth Indicators } & \multicolumn{5}{c}{ Treatments } \\
\cline { 2 - 6 } & T1 & T2 & T3 & T4 & T5 \\
\hline Initial weight (g) & $4.13 \pm 0.01^{\mathrm{a}}$ & $4.11 \pm 0.03^{\mathrm{a}}$ & $4.10 \pm 0.01^{\mathrm{a}}$ & $4.15 \pm 0.04^{\mathrm{a}}$ & $4.11 \pm 0.03^{\mathrm{a}}$ \\
Final weight (g) & $20.98 \pm 0.24^{\mathrm{a}}$ & $20.42 \pm 0.43^{\mathrm{a}}$ & $14.95 \pm 0.25^{\mathrm{b}}$ & $20.05^{\mathrm{a}} \pm 0.77^{\mathrm{a}}$ & $17.31 \pm 0.92^{\mathrm{c}}$ \\
Weight gain (g) & $16.85 \pm 0.25^{\mathrm{a}}$ & $16.30 \pm 0.46^{\mathrm{a}}$ & $10.84 \pm 0.24^{\mathrm{b}}$ & $15.85 \pm 0.78^{\mathrm{a}}$ & $13.20 \pm 0.89^{\mathrm{c}}$ \\
Initial biomass weight (g) & $61.91 \pm 0.14^{\mathrm{a}}$ & $61.70 \pm 0.43^{\mathrm{a}}$ & $61.57 \pm 0.14^{\mathrm{a}}$ & $62.27 \pm 0.57^{\mathrm{a}}$ & $61.70 \pm 0.43^{\mathrm{a}}$ \\
Final biomass weight (g) & $286.82 \pm 14.95^{\mathrm{a}}$ & $272.20 \pm 13.03^{\mathrm{ab}}$ & $135.00 \pm 1.75^{\mathrm{c}}$ & $251.18 \pm 2.73^{\mathrm{b}}$ & $177.15 \pm 12.78^{\mathrm{d}}$ \\
Total biomass gain (g) & $224.91 \pm 15.07^{\mathrm{a}}$ & $210.50 \pm 13.22^{\mathrm{ab}}$ & $73.43 \pm 1.61^{\mathrm{c}}$ & $188.90 \pm 2.75^{\mathrm{b}}$ & $115.44 \pm 12.36^{\mathrm{d}}$ \\
SGR (\%) & $2.69 \pm 0.10^{\mathrm{a}}$ & $2.60 \pm 0.09^{\mathrm{ab}}$ & $1.38 \pm 0.02^{\mathrm{c}}$ & $2.45 \pm 0.02^{\mathrm{b}}$ & $1.85 \pm 0.12^{\mathrm{d}}$ \\
FI per fish (g) & $42.04 \pm 0.58^{\mathrm{a}}$ & $40.53 \pm 0.64^{\mathrm{ab}}$ & $20.43 \pm 0.70^{\mathrm{c}}$ & $38.71 \pm 1.46^{\mathrm{b}}$ & $28.73 \pm 0.77^{\mathrm{d}}$ \\
FCR & $2.61 \pm 0.22^{\mathrm{a}}$ & $3.04 \pm 0.10^{\mathrm{ab}}$ & $5.50 \pm 0.28^{\mathrm{c}}$ & $3.20 \pm 0.04^{\mathrm{b}}$ & $3.99 \pm 0.19^{\mathrm{d}}$ \\
FER & $0.38 \pm 0.03^{\mathrm{a}}$ & $0.33 \pm 0.01^{\mathrm{b}}$ & $0.18 \pm 0.01^{\mathrm{c}}$ & $0.31 \pm 0.00^{\mathrm{b}}$ & $0.25 \pm 0.01^{\mathrm{d}}$ \\
PER & $1.18 \pm 0.01^{\mathrm{a}}$ & $1.18 \pm 0.04^{\mathrm{a}}$ & $1.57 \pm 0.06^{\mathrm{b}}$ & $1.19 \pm 0.02^{\mathrm{a}}$ & $1.33 \pm 0.04^{\mathrm{c}}$ \\
\hline Final number (fish/tank) & $13.67 \pm 0.58^{\mathrm{a}}$ & $13.33 \pm 0.58^{\mathrm{a}}$ & $9.00 \pm 0.00^{\mathrm{b}}$ & $12.67 \pm 0.58^{\mathrm{a}}$ & $10.33^{\mathrm{a}} \pm 0.58^{\mathrm{b}}$ \\
Survival (\%) & $91.11 \pm 3.85^{\mathrm{a}}$ & $88.89 \pm 3.85^{\mathrm{a}}$ & $60.00 \pm 0.00^{\mathrm{b}}$ & $84.45^{\mathrm{a}} \pm 3.85^{\mathrm{a}}$ & $68.89 \pm 3.85^{\mathrm{b}}$ \\
\hline
\end{tabular}

Values are means of the experimental treatments \pm SD, values marked with different superscript letters in the same row are significantly different $(p<0.05)$. SGR: Specific growth rate, FI: Feed intake (g), FCR: Feed conversion ratio. FER: Feed efficiency ratio. PER: Protein efficiency ratio. T1: commercial feed 100\%; T2: freeze-dried bioflocs $4 \%$; T3: freeze-dried bioflocs $16 \%$; T4: oven-dried bioflocs $4 \%$; T5: oven-dried bioflocs $16 \%$.

From Table 1, no significant differences were found between the means of $\mathrm{T} 2$ and T4 treatments for all growth indicators. Similarly, no significant differences were found between the means of T1 and T2 treatments for all growth indicators, except for the feed efficiency ratio (FER). However, significant differences were found between T1 and $\mathrm{T} 4$ treatments in terms of final biomass weights, total biomass gains, specific growth rate (\% SGR), feed intake per fish (FI), feed conversion ratio (FCR), and FER, but no significant differences in terms of initial weights, final weights, weight gains, initial biomass weights, protein efficiency ratio (PER) and survival rate (\% SR) between the same treatments (Table 1). Furthermore, clear significant differences were observed within the means of body weight for T3 and T5 treatments compared to the T1 treatment (Figure 1). Again, clear significant differences were observed between the means of final body weight for T3 and T5 treatments at the end of the experiment (Table 1, Figure 1).

Statistically, T2 and T4 treatments had significantly higher values of growth performance than T3 and T5 treatments in terms of final weights, weight gains, final biomass weights, total biomass gains, \% SGR, FI per fish, FER, and \% SR. However, T2 and T4 treatments showed significantly lower values in terms of FCR and PER. No significant differences were found within the means of T1, T2, and T4 treatments in terms of final weights, weight gains, PER, and \% SR (Table 1, Figure 1). 


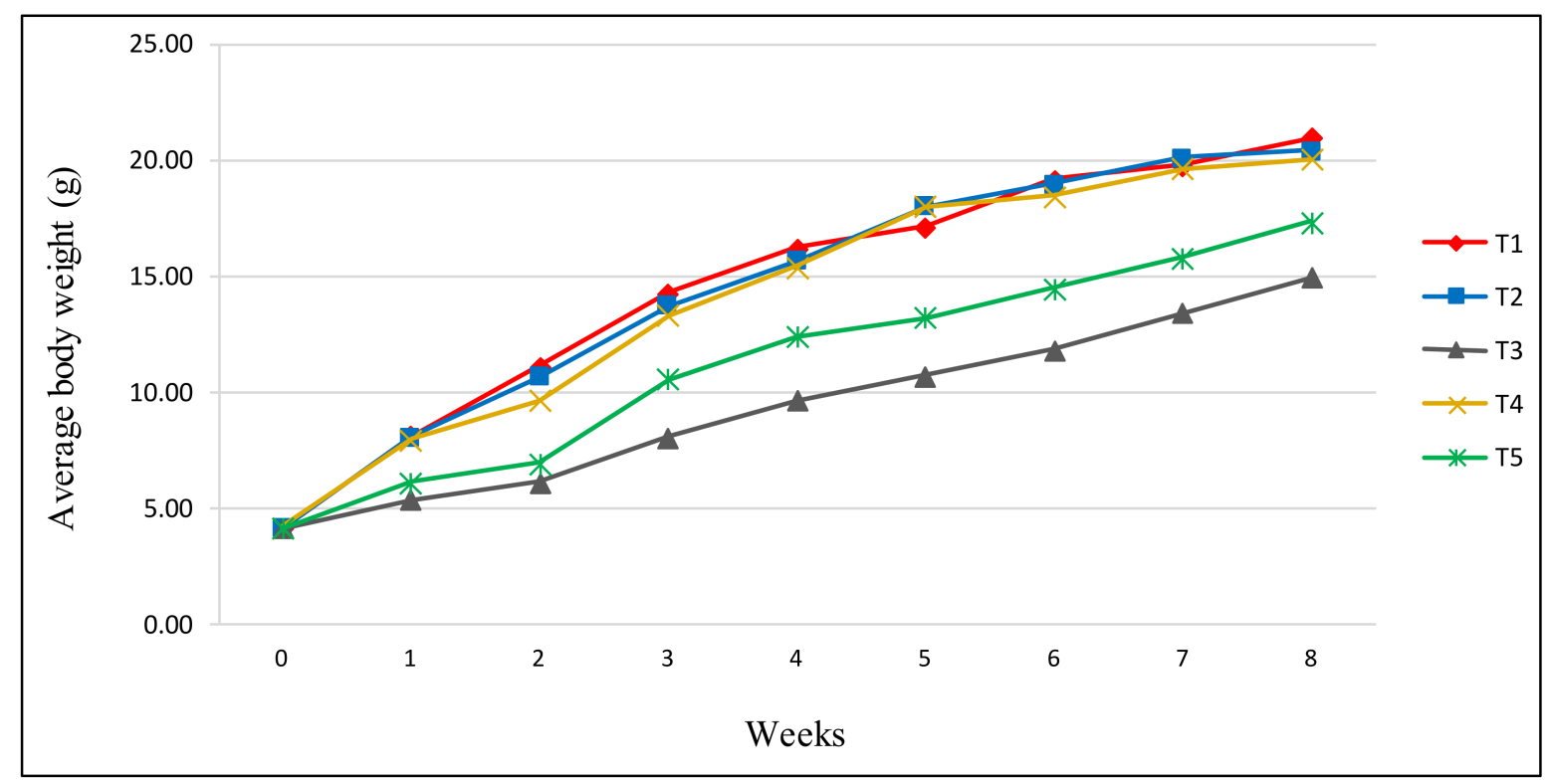

Figure 1. The changes in average body weights (g) during the period of the feeding trial.

Although T4 treatment showed significantly lower values of final biomass weight, total biomass gain, \% SGR, FI, and FER, and higher value of FCR compared to T1 treatments, these values were significantly higher than those for T5 and T3 treatments. While FCR was significantly lower for $\mathrm{T} 4$ treatments than $\mathrm{T} 5$ and $\mathrm{T} 3$ treatments, it was higher compared to T1 treatments. Moreover, no significant differences were observed between T2 and T4 treatments in terms of final biomass weight, total biomass gain, \% SGR, FI, FCR, and FER. At the same time, no significant differences were observed between T1 and T2 treatments in the same growth indicators at the end of the experiment (Table 1).

On the other hand, water quality results also showed significant differences within the means of the five treatments for all water quality parameters, but no significant differences were recorded for salinity as shown in Table 2.

During the eight weeks of the experiment, parameters of temperature, dissolved oxygen (DO) and $\mathrm{pH}$ value ranged from $25.4-28.3^{\circ} \mathrm{C}, 7.08-10.87 \mathrm{ppm}$, and $7.44-8.37 \mathrm{pH}$, respectively for all treatments in the present study. The temperature degrees for T2 and T4 treatments were significantly higher than $\mathrm{T} 1$ treatment but significantly lower than those degrees for $\mathrm{T} 3$ and T5 treatments (Table 2). Even though T5 treatment recorded significantly higher temperatures, $\mathrm{T} 3$ treatment had the highest temperature in the present study (Table 2). DO levels were significantly lower for $\mathrm{T} 3$ and $\mathrm{T} 5$ treatments compared to $\mathrm{T} 1$ treatment, while no significant differences were observed within $\mathrm{T} 1, \mathrm{~T} 2$, and $\mathrm{T} 4$ treatments. In terms of $\mathrm{pH}$ values, $\mathrm{T} 2$ treatment showed a $\mathrm{pH}$ value significantly similar to $\mathrm{T} 1$ treatment followed by $\mathrm{T} 4$ treatment, which showed no significant difference with $\mathrm{T} 2$ treatment but was significantly lower than $\mathrm{T} 1$ treatment. Meanwhile, $\mathrm{pH}$ values for $\mathrm{T} 3$ and $\mathrm{T} 5$ treatments were significantly lower than $\mathrm{pH}$ values for $\mathrm{T} 1, \mathrm{~T} 2$, and $\mathrm{T} 4$ treatments (Table 2).

Values of salinity, electrical conductivity (EC), total dissolved solids (TDS), and total suspended solids (TSS) ranged from $9.00-10.85 \mathrm{ppt}, 12.22-18.35 \mathrm{mS} / \mathrm{cm}, 10.09-11.97 \mathrm{ppt}$, and 7.50-29.00 ppm, respectively for all treatments during the 57 days of feeding trials. Although no significant differences were found among the means of all treatments in terms of salinity, EC values for T3 and T5 treatments were significantly higher than those values for T2 and T4 treatments, while T1 treatment showed significantly the lowest value of EC. However, no significant difference was found between T1 and T4 treatments for TDS and TSS levels. Moreover, T2 treatment showed TDS level significantly similar to T1 treatment, but significantly higher than T4 treatment. Furthermore, the TSS level for T2 treatment was significantly higher compared to T1 and T4 treatments. However, T3 and T5 treatments 
had the highest levels of TDS and TSS in the present study. Where T3 treatment was significantly higher than T5 treatment in terms of TDS and TSS (Table 2).

Table 2. Water quality parameters during the experiment period of 57 days (mean \pm SD followed by minimum and maximum values).

\begin{tabular}{|c|c|c|c|c|c|}
\hline \multirow{2}{*}{ Parameters } & \multicolumn{5}{|c|}{ Treatments } \\
\hline & T1 & $\mathrm{T} 2$ & T3 & $\mathrm{T} 4$ & T5 \\
\hline $\mathrm{T}^{\circ}\left(\mathrm{C}^{\circ}\right)$ & $\begin{array}{c}26.22 \pm 0.03^{\mathrm{a}} \\
\quad(25.6-28.1)\end{array}$ & $\begin{array}{c}26.27 \pm 0.02^{b} \\
(25.7-28.1)\end{array}$ & $\begin{array}{c}26.39 \pm 0.03^{c} \\
(25.7-28.3)\end{array}$ & $\begin{array}{c}26.28 \pm 0.02^{b} \\
(25.4-28.1)\end{array}$ & $\begin{array}{c}26.33 \pm 0.01^{\mathrm{d}} \\
\quad(25.5-28.2)\end{array}$ \\
\hline $\mathrm{DO}$ (ppm) & $\begin{array}{c}9.16 \pm 0.09^{a} \\
(7.71-10.87)\end{array}$ & $\begin{array}{c}9.07 \pm 0.05^{\mathrm{a}} \\
(7.74-10.82)\end{array}$ & $\begin{array}{c}7.98 \pm 0.01^{b} \\
(7.08-8.62)\end{array}$ & $\begin{array}{c}9.08 \pm 0.01^{\mathrm{a}} \\
(7.63-10.54)\end{array}$ & $\begin{array}{c}8.09 \pm 0.03^{b} \\
(7.49-8.88)\end{array}$ \\
\hline $\mathrm{pH}$ & $\begin{array}{l}7.90 \pm 0.02^{\mathrm{a}} \\
(7.60-8.37)\end{array}$ & $\begin{array}{c}7.87 \pm 0.02^{a b} \\
(7.51-8.30)\end{array}$ & $\begin{array}{c}7.68 \pm 0.01^{\mathrm{c}} \\
(7.44-7.98)\end{array}$ & $\begin{array}{c}7.84 \pm 0.01^{b} \\
(7.53-8.24)\end{array}$ & $\begin{array}{l}7.74 \pm 0.01^{\mathrm{d}} \\
(7.50-8.05)\end{array}$ \\
\hline Salinity (ppt) & $\begin{array}{c}10.04 \pm 0.04^{\mathrm{a}} \\
(9.00-10.36)\end{array}$ & $\begin{array}{c}10.01 \pm 0.02^{\mathrm{a}} \\
(9.00-10.50)\end{array}$ & $\begin{array}{c}10.07 \pm 0.01^{\mathrm{a}} \\
(9.30-10.53)\end{array}$ & $\begin{array}{c}9.98 \pm 0.05^{\mathrm{a}} \\
(8.80-10.85)\end{array}$ & $\begin{array}{c}10.04 \pm 0.06^{\mathrm{a}} \\
(9.10-10.40)\end{array}$ \\
\hline $\mathrm{EC}(m \mathrm{~S} / \mathrm{cm})$ & $\begin{array}{l}15.85 \pm 0.03^{a} \\
(12.62-17.61)\end{array}$ & $\begin{array}{l}16.08 \pm 0.03^{b} \\
(12.22-17.54)\end{array}$ & $\begin{array}{l}16.65 \pm 0.13^{c} \\
(12.86-18.35)\end{array}$ & $\begin{array}{l}16.09 \pm 0.03^{b} \\
(12.64-17.80)\end{array}$ & $\begin{array}{l}16.59 \pm 0.06^{\mathrm{c}} \\
(12.22-18.03)\end{array}$ \\
\hline TDS (ppt) & $\begin{array}{c}10.52 \pm 0.05^{\mathrm{ab}} \\
(10.09-10.75)\end{array}$ & $\begin{array}{c}10.62 \pm 0.03^{a} \\
(10.38-11.30)\end{array}$ & $\begin{array}{l}11.69 \pm 0.08^{c} \\
(10.25-11.97)\end{array}$ & $\begin{array}{c}10.48 \pm 0.001^{\mathrm{b}} \\
(10.38-10.60)\end{array}$ & $\begin{array}{c}11.35 \pm 0.05^{\mathrm{d}} \\
(10.69-11.92)\end{array}$ \\
\hline TSS (ppm) & $\begin{array}{c}13.39 \pm 0.14^{\mathrm{a}} \\
(7.50-18.00)\end{array}$ & $\begin{array}{c}16.48 \pm 0.29^{b} \\
(11.00-20.80)\end{array}$ & $\begin{array}{c}20.19 \pm 0.59^{c} \\
(16.00-29.00)\end{array}$ & $\begin{array}{c}14.18 \pm 0.02^{\mathrm{a}} \\
(9.40-19.40)\end{array}$ & $\begin{array}{c}18.28 \pm 0.17^{\mathrm{d}} \\
(12.00-27.00)\end{array}$ \\
\hline TAN (ppm) & $\begin{array}{c}1.21 \pm 0.02^{\mathrm{a}} \\
(0.08-1.95)\end{array}$ & $\begin{array}{c}1.26 \pm 0.06^{\mathrm{b}} \\
(0.09-1.92)\end{array}$ & $\begin{array}{c}1.59 \pm 0.02^{\mathrm{c}} \\
(0.10-2.29)\end{array}$ & $\begin{array}{c}1.23 \pm 0.02^{\mathrm{ab}} \\
(0.09-1.94)\end{array}$ & $\begin{array}{c}1.36 \pm 0.02^{\mathrm{d}} \\
(0.10-2.25)\end{array}$ \\
\hline $\mathrm{NO}_{3}-\mathrm{N}(\mathrm{ppm})$ & $\begin{array}{c}1.58 \pm 0.01^{\mathrm{a}} \\
(0.83-2.20)\end{array}$ & $\begin{array}{c}1.70 \pm 0.01^{b} \\
(0.90-2.40)\end{array}$ & $\begin{array}{c}2.36 \pm 0.08^{\mathrm{c}} \\
(1.06-3.63)\end{array}$ & $\begin{array}{c}1.58 \pm 0.03^{\mathrm{a}} \\
(0.80-2.20)\end{array}$ & $\begin{array}{c}2.23 \pm 0.03^{d} \\
(0.95-3.33)\end{array}$ \\
\hline $\mathrm{PO}_{4}^{-}(\mathrm{ppm})$ & $\begin{array}{c}3.45 \pm 0.64^{\mathrm{a}} \\
(1.80-10.00)\end{array}$ & $\begin{array}{c}3.83 \pm 0.14^{\mathrm{a}} \\
(2.20-11.00)\end{array}$ & $\begin{array}{c}10.57 \pm 0.99 \mathrm{~b} \\
(3.10-12.90)\end{array}$ & $\begin{array}{c}3.62 \pm 1.02^{\mathrm{a}} \\
(1.90-9.30)\end{array}$ & $\begin{array}{l}7.76 \pm 0.03^{c} \\
(2.40-11.10)\end{array}$ \\
\hline BOD (ppm) & $\begin{array}{c}1.96 \pm 0.18^{\mathrm{a}} \\
(1.10-4.19)\end{array}$ & $\begin{array}{c}2.28 \pm 0.05^{\mathrm{ac}} \\
(1.45-4.20)\end{array}$ & $\begin{array}{c}5.22 \pm 0.97^{\mathrm{b}} \\
(2.10-9.47)\end{array}$ & $\begin{array}{c}2.14 \pm 0.44^{\mathrm{a}} \\
(1.17-3.51)\end{array}$ & $\begin{array}{c}3.56 \pm 0.04^{\mathrm{c}} \\
(1.52-5.35)\end{array}$ \\
\hline COD (ppm) & $\begin{array}{l}204.10 \pm 3.82^{\mathrm{a}} \\
\quad(110-308)\end{array}$ & $\begin{array}{c}233.90 \pm 3.94^{b} \\
(110-348)\end{array}$ & $\begin{array}{c}373.65 \pm 5.48^{c} \\
(160-499)\end{array}$ & $\begin{array}{c}201.17 \pm 12.67^{a} \\
(90-358)\end{array}$ & $\begin{array}{c}317.15 \pm 6.40^{\mathrm{d}} \\
\quad(170-455)\end{array}$ \\
\hline
\end{tabular}

Values marked with different superscript letters in the same row are significantly different $(p<0.05)$. T1 treatment: commercial feed $100 \%$; T2 treatment: freeze-dried bioflocs at $4 \%$; T3 treatment: freeze-dried bioflocs at $16 \%$; T4 treatment: oven-dried bioflocs at 4\%; T5 treatment: oven-dried bioflocs at $16 \%$.

Concentrations of total ammonia-nitrogen (TAN), nitrate-nitrogen $\left(\mathrm{NO}_{3}-\mathrm{N}\right)$, and phosphate $\left(\mathrm{PO}_{4}^{-}\right)$ranged from $0.08-2.29,0.80-3.63$, and $1.80-12.90 \mathrm{ppm}$, respectively. The concentrations of TAN and $\mathrm{NO}_{3}-\mathrm{N}$ were significantly higher for T2 treatment compared to $\mathrm{T} 1$ treatment, while $\mathrm{T} 4$ treatment showed concentrations of TAN and $\mathrm{NO}_{3}-\mathrm{N}$ similar to $\mathrm{T} 1$ treatment. In addition, no significant difference was recorded between T2 and T4 treatments in terms of TAN, while a clear significant difference was recorded between $\mathrm{T} 2$ and $\mathrm{T} 4$ treatments for $\mathrm{NO}_{3}-\mathrm{N}$. However, concentrations of $\mathrm{PO}_{4}{ }^{-}$for $\mathrm{T} 1, \mathrm{~T} 2$, and $\mathrm{T} 4$ treatments were significantly similar. Meanwhile, $\mathrm{T} 3$ and $\mathrm{T} 5$ treatments showed the highest concentrations of TAN, $\mathrm{NO}_{3}-\mathrm{N}$, and $\mathrm{PO}_{4}{ }^{-}$in the present study (Table 2).

Results of BOD and COD also showed significant differences among the five treatments in the present study (Table 2). However, no significant differences were found within the means of T1, T2, and T3 treatments for BOD. However, T2 treatment was significantly higher compared to $\mathrm{T} 1$ and $\mathrm{T} 4$ treatments in terms of $\mathrm{COD}$, while $\mathrm{T} 3$ treatment showed higher values of BOD and COD than T5 treatment. Both treatments of T3 and T5 were significantly higher compared to T1, T2, and T4 treatments. It is evident that the different ratios of bioflocs have more effect on water quality parameters than the drying methods did. From the statistical analysis of data, there was a significant effect of using two different ratios of dried bioflocs in the formulation of diets for red hybrid tilapia on the water quality of culture tanks. It can be noticed that T2 and T4 treatments (4\% freeze-dried and oven-dried bioflocs) showed water quality values similar or closer to the control and resulted in better water quality parameters. Meanwhile T3 treatment (16\% freeze-dried bioflocs) showed the worst quality of culture water followed by $\mathrm{T} 5$ treatment ( $16 \%$ oven-dried bioflocs). 
Results of proximate composition analyses for bioflocs, experimental diets, and final fish body composition were presented in Table 3. However, a comparison between the means of freeze-dried bioflocs (FDBF) and oven-dried bioflocs (ODBF) showed no significant differences for organic matter, moisture, crude fiber, total ash, and energy. However, significant differences were found for crude protein, crude lipid, and total nitrogen-free extraction (NFE). Statistically, FDBF had significantly higher protein content than ODBF, however, ODBF had significantly higher lipid and NFE contents than those contents for FDBF (Table 3).

Table 3. Proximate composition (g/100 g, dry weight or fish wet weight) of experimental diets, bioflocs, and fish body composition (mean $\pm \mathrm{SD}$ ).

\begin{tabular}{|c|c|c|c|c|c|c|c|c|}
\hline \multirow{2}{*}{ Treatments } & \multicolumn{8}{|c|}{ Proximate Composition (\%) } \\
\hline & OM & Moisture & Crude Protein & Crude Lipid & Crude Fiber & Total NFE & Total Ash & Gross Energy \\
\hline \multicolumn{9}{|c|}{ Bioflocs ${ }^{1}$ (in dry weight) } \\
\hline FDBF & $58.45 \pm 1.14^{\mathrm{a}}$ & $8.37 \pm 0.19^{a b}$ & $30.55 \pm 0.39^{a}$ & $0.78 \pm 0.02^{\mathrm{a}}$ & $15.84 \pm 0.17^{\mathrm{a}}$ & $2.92 \pm 1.04^{\mathrm{a}}$ & $41.55 \pm 1.14^{\mathrm{a}}$ & $255.34 \pm 4.63^{\mathrm{a}}$ \\
\hline ODBF & $60.12 \pm 1.11^{\mathrm{a}}$ & $6.92 \pm 0.39^{a}$ & $26.18 \pm 1.23^{b}$ & $0.96 \pm 0.05^{b}$ & $16.58 \pm 0.22^{a}$ & $9.48 \pm 0.34^{b}$ & $39.88 \pm 1.11^{\mathrm{a}}$ & $262.49 \pm 6.82^{\mathrm{a}}$ \\
\hline \multicolumn{9}{|c|}{ Experimental diets ${ }^{2}$ (in dry weight) } \\
\hline $\mathrm{T} 1$ & $85.06 \pm 0.05^{b}$ & $9.95 \pm 0.01^{b}$ & $33.34 \pm 1.29^{\mathrm{c}}$ & $5.55 \pm 0.07^{\mathrm{c}}$ & $7.51 \pm 0.40^{b}$ & $28.72 \pm 1.57^{c}$ & $14.94 \pm 0.05^{b}$ & $387.59 \pm 1.79^{b}$ \\
\hline $\mathrm{T} 2$ & $88.79 \pm 0.41^{c}$ & $4.80 \pm 0.39^{c}$ & $32.25 \pm 0.37^{\mathrm{ac}}$ & $4.88 \pm 0.04^{\mathrm{d}}$ & $8.12 \pm 0.31^{b}$ & $38.75 \pm 0.85^{\mathrm{d}}$ & $11.21 \pm 0.41^{\mathrm{c}}$ & $418.79 \pm 2.92^{\mathrm{c}}$ \\
\hline T3 & $88.72 \pm 0.02^{c}$ & $4.63 \pm 0.51^{\mathrm{c}}$ & $27.05 \pm 0.96^{b}$ & $4.59 \pm 0.03^{\mathrm{e}}$ & $10.38 \pm 0.30^{c}$ & $42.07 \pm 0.65 \mathrm{de}$ & $11.28 \pm 0.02^{c}$ & $409.86 \pm 3.18^{c}$ \\
\hline $\mathrm{T} 4$ & $88.26 \pm 3.24^{c}$ & $4.29 \pm 0.05^{c}$ & $31.15 \pm 0.43^{\mathrm{ac}}$ & $5.15 \pm 0.10^{\mathrm{f}}$ & $8.27 \pm 0.56^{\mathrm{b}}$ & $39.40 \pm 3.88^{\text {de }}$ & $11.74 \pm 3.24^{\mathrm{c}}$ & $418.49 \pm 13.34^{c}$ \\
\hline T5 & $88.79 \pm 0.41^{\mathrm{c}}$ & $4.22 \pm 0.54^{\mathrm{c}}$ & $25.75 \pm 0.92^{b}$ & $4.70 \pm 0.01 \mathrm{e}$ & $9.86 \pm 0.76^{c}$ & $44.25 \pm 1.47^{\mathrm{e}}$ & $11.22 \pm 0.41^{c}$ & $410.48 \pm 2.23^{c}$ \\
\hline \multicolumn{9}{|c|}{ Fish body composition (in wet weight) } \\
\hline Initial & $96.81 \pm 0.12^{\mathrm{A}}$ & $84.59 \pm 0.31^{\mathrm{A}}$ & $09.04 \pm 0.25^{\mathrm{A}}$ & $1.59 \pm 0.04^{\mathrm{A}}$ & $0.65 \pm 0.06^{\mathrm{A}}$ & $0.95 \pm 0.13^{\mathrm{AC}}$ & $3.19 \pm 0.12 \mathrm{~A}$ & $72.18 \pm 1.37^{\mathrm{A}}$ \\
\hline $\mathrm{T} 1$ & $96.55 \pm 0.23 \mathrm{AB}$ & $73.60 \pm 1.13 \mathrm{BD}$ & $13.72 \pm 0.40^{\mathrm{B}}$ & $4.67 \pm 0.20^{\mathrm{B}}$ & $3.62 \pm 0.10^{\mathrm{B}}$ & $0.94 \pm 0.46^{\mathrm{AC}}$ & $3.45 \pm 0.23 \mathrm{AB}$ & $139.58 \pm 5.27^{\mathrm{B}}$ \\
\hline $\mathrm{T} 2$ & $96.66 \pm 0.09 \mathrm{~A}$ & $74.08 \pm 1.07 \mathrm{BD}$ & $13.51 \pm 0.52^{\text {в }}$ & $4.52 \pm 0.15^{\mathrm{B}}$ & $3.74 \pm 0.16^{\mathrm{B}}$ & $0.82 \pm 0.18^{\mathrm{ABC}}$ & $3.34 \pm 0.09 \mathrm{~A}$ & $137.02 \pm 5.66^{\mathrm{BD}}$ \\
\hline $\mathrm{T} 3$ & $96.23 \pm 0.02^{\text {B }}$ & $76.02 \pm 0.52^{\mathrm{C}}$ & $12.08 \pm 0.24^{\mathrm{C}}$ & $4.32 \pm 0.15^{\text {В }}$ & $3.65 \pm 0.11^{\text {B }}$ & $0.17 \pm 0.06^{\mathrm{B}}$ & $3.77 \pm 0.02^{\text {в }}$ & $124.00 \pm 3.03^{C}$ \\
\hline $\mathrm{T} 4$ & $96.59 \pm 0.10 \mathrm{AB}$ & $72.86 \pm 0.03^{\mathrm{D}}$ & $14.05 \pm 0.15^{\text {в }}$ & $4.66 \pm 0.02^{\text {в }}$ & $3.68 \pm 0.03^{\text {в }}$ & $1.33 \pm 0.19^{\mathrm{C}}$ & $3.41 \pm 0.10^{\mathrm{AB}}$ & $143.27 \pm 0.49^{\text {в }}$ \\
\hline T5 & $96.45 \pm 0.19$ АВ & $75.27 \pm 0.29 \mathrm{BC}$ & $12.52 \pm 0.29^{C}$ & $4.43 \pm 0.14^{\text {В }}$ & $3.88 \pm 0.10^{\text {В }}$ & $0.76 \pm 0.45^{\mathrm{AB}}$ & $3.55 \pm 0.19 \mathrm{AB}$ & $129.27 \pm 2.00 \mathrm{CD}$ \\
\hline
\end{tabular}

Different superscript small letters in the same column indicate the significant differences among means of bioflocs and experimental diets in dry matter, while different superscript capital letters indicate the significant differences within means of proximate compositions of the whole body of initial and final tilapia fish in the wet matter $(p<0.5)$ ${ }^{1}$ FDBF; Freeze-dried bioflocs. ODBF; Oven-dried bioflocs. ${ }^{2}$ Experimental diets: T1 diet; $100 \%$ commercial feed without bioflocs (as a control diet), T2 diet; 4\% FDBF, T3 diet; 16\% FDBF, T4 diet; 4\% ODBF, and T5 diet; 16\% ODBF.

For the experimental diets, organic matter and energy contents were significantly higher in T2, T3, T4, and T5 diets compared to the T1 diet (Table 3). Meanwhile, moisture and ash contents were significantly lower in $\mathrm{T} 2, \mathrm{~T} 3, \mathrm{~T} 4$, and $\mathrm{T} 5$ diets compared to the $\mathrm{T} 1$ diet. No significant differences were noticed within the means of T1, T2, and T4 diets for protein and fiber contents, while T3 and T5 diets showed significantly lower protein content compared to the $\mathrm{T} 1$ diet, but significantly higher fiber content than the T1 diet. The highest crude lipid content was for the T1 diet, while the lowest contents of lipid were recorded for T3 and T5 diets. However, the T1 diet showed the lowest content of total NFE, while the T5 diet showed the highest NFE content followed by T3 and T4 diets. T2 diet showed NFE content significantly higher than the T1 diet, but significantly lower than the T5 diet (Table 3).

From Table 3, proximate compositions of the final fish whole-body of red hybrid tilapia from the five treatments showed significant differences among the values of OM, moisture, crude protein, total NFE, total ash, and gross energy, while no significant differences were observed among the means of final fish body compositions in terms of crude lipid and crude fiber. Moisture contents for T1, T2, and T4 treatments were significantly lower than $\mathrm{T} 3$ treatment, while $\mathrm{T} 5$ treatment showed no significant differences compared to T1 and $\mathrm{T} 2$ treatments (Table 3). The highest protein content was for T4 treatment followed by T1 and T2 treatments. Meanwhile, T3 and T5 treatments showed significantly lower protein contents compared to T1, T2, and T4 treatments. T4 treatment also showed the highest NFE and energy contents followed again by T1 and T2 treatments (Table 3).

However, values of moisture, protein, lipid, fiber, and energy of the final fish body compositions were significantly different compared to values of these proximate from the initial fish body composition at the start-up of the experiment. The initial protein, lipid, fiber, and energy contents were significantly lower than those contents in the final 
compositions of red hybrid tilapia. The moisture content of the initial fish composition was significantly higher than in the final red hybrid tilapia compositions (Table 3).

\section{Discussion}

The drying methods (freeze-drying and oven-drying) in the present study did not affect the growth performance of red hybrid tilapia, while the levels of bioflocs had a significant effect on growth in terms of final weights, weight gains, final biomass weights, total biomass gains, specific growth rate (\% SGR), feed intake (FI), feed conversion ratio (FCR), feed efficiency ratio (FER), protein efficiency ratio (PER), and survival rate (\% SR).

In fish growth studies, it is known that the growth rate is considered the most effective parameter to examine the effect of any experimental factor on fish [24]. In the present study, the ratio of $4 \%$ freeze-dried and oven-dried bioflocs had a higher growth rate (final weights, weight gains, $\%$ SGR, and \% SR) similar to the control. However, the ratio of $16 \%$ freeze-dried and oven-dried bioflocs had a lesser growth rate compared to the ratio of $4 \%$.

Environmentally, uneaten feed or waste feed could be resulting in poor water quality parameters in culture water [45]. In the present study, the uneaten feed by the fish in each tank was siphoned, filtered, dried, and then weighed to calculate the total consumed feed per tank during the 57 days of tilapia rearing [46]. We found that the weights of uneaten feed for 3 and 5 treatments (fed 16\% bioflocs diets) were higher than the weight of uneaten feed for T1 (the control), T2, and T4 treatments. Accordingly, the FI values for the control and treatments fed $4 \%$ bioflocs were significantly higher compared to treatments fed $16 \%$ bioflocs in the present study. Therefore, the decrease in the FI values for T3 and T5 treatments was due to the increase of weight of uneaten feed for the same treatments.

The growth results from the present study demonstrated that supplementation of $4 \%$ freeze-dried bioflocs can efficiently affect the growth rate of red hybrid tilapia, followed by supplementation of $4 \%$ oven-dried bioflocs. Lee et al. [15] also demonstrated the possibility of using freeze-dried bioflocs as a dietary supplement at a $4 \%$ ratio, and their study showed beneficial effects on the growth rate of Pacific white shrimp (Litopenaeus vannamei). Furthermore, Shyne Anand et al. [13] reported that the inclusion of $4 \%$ oven-dried bioflocs in the diet can enhance the growth performance of tiger shrimp (Penaeus monodon).

The performance of red hybrid tilapia in the present study was significantly affected by the different ratios of dried bioflocs $(4 \%$ and $16 \%$ ) produced by both drying methods (freeze-drying and oven-drying), where the ratio of $4 \%$ dried bioflocs showed better values of growth compared to the ratio of $16 \%$ dried bioflocs. While the drying methods had a lesser effect than the ratios of dried bioflocs, however, $16 \%$ freeze-dried and/or ovendried bioflocs diets clearly affected the growth indicators of red hybrid tilapia, where $16 \%$ oven-dried bioflocs diet showed better values of growth than $16 \%$ freeze-dried bioflocs diet. No effect of the drying methods was observed by using the ratio of $4 \%$ dried bioflocs. Moreover, the $4 \%$ ratio showed better values of growth performance similar to the control ( $0 \%$ bioflocs). Therefore, the ratio of $4 \%$ dried bioflocs (freeze-dried and/or oven-dried bioflocs) can be included in red hybrid tilapia diets without any effect on the growth performance of tilapia.

On the other hand, water quality parameters were also affected by the ratios of dried bioflocs more than the drying methods. All parameters of water quality, except for salinity, showed clear significant differences among the means of $4 \%$ and $16 \%$ dried bioflocs diets. In contrast, the drying methods showed effects only on bioflocs diets at a ratio of $16 \%$, while no significant difference was observed between bioflocs diets at a ratio of $4 \%$ dried bioflocs produced by freeze-drying and oven-drying methods.

From the water quality results, the values of $\mathrm{DO}, \mathrm{pH}$, and $\mathrm{EC}$ might be influenced by the water temperature inside the tanks. Bioflocs treatments (T3 and T5 treatments) showed lower DO levels, but higher temperature compared to the control (T1 treatment). In this respect, it is known that there is an inverse relationship between temperature and the level of dissolved oxygen in water [47]. Similar to DO levels, $\mathrm{pH}$ values can be influenced by temperature since there is also an inverse relationship between temperature and $\mathrm{pH}$ in 
water [48]. Values of $\mathrm{pH}$ for the bioflocs treatments in the present study were significantly lower, but the T2 treatment showed a $\mathrm{pH}$ value closer to the control. Although the control treatment and $\mathrm{T} 2$ treatment showed no significant difference in $\mathrm{pH}$ values, a slight decrease was noticed for T2 treatment. Meanwhile, the higher temperature in the bioflocs treatments might cause an increase in the EC values. Hayashi [49] reported that there is a direct linear relationship between temperature and conductivity (EC) values in water. For example, increasing $1{ }^{\circ} \mathrm{C}$ in temperature causes increasing of $2 \%$ in EC value [49]. Therefore, the decrease in $\mathrm{DO}$ and $\mathrm{pH}$ values, as well as the increase in EC values for bioflocs treatments in the present study, may be due to the increase in temperature for the same treatments.

It is very important to understand the biological cycle of nitrogen, which is known as nitrification [50]. Ammonia (TAN) is the first product of the nitrification process of nitrogen cycle inside culture tanks, due to the decomposition of waste organic matters (uneaten feed) or excreted by most fish and other aquatic organisms [24]. High levels of ammonia, which is the most toxic nitrogen compound, can reduce growth and lead to significant losses in the production of fish [51]. TAN is converted to nitrite $\left(\mathrm{NO}_{2}-\mathrm{N}\right)$ by nitrosomonas bacteria, then, $\mathrm{NO}_{2}-\mathrm{N}$, which is also extremely toxic to fish, is converted to $\mathrm{NO}_{3}-\mathrm{N}$ by nitrobacter bacteria [52]. These reactions are affected by water temperature and $\mathrm{NO}_{2}-\mathrm{N}$ is rapidly converted to $\mathrm{NO}_{3}-\mathrm{N}$, so $\mathrm{NO}_{2}-\mathrm{N}$ levels are usually not easy to be measured [45]. For this reason, ammonia levels tend to be higher before nitrification rates have increased as a result of increasing temperatures. However, $\mathrm{NO}_{3}-\mathrm{N}$, the final product of the nitrogen cycle, is less toxic compared to ammonia, however, excessive levels of nitrate can affect the health and performance of fish [53].

In aquaculture systems, waste feed (uneaten feed) is the major source of nitrogen $(\mathrm{N})$ in the forms of $\mathrm{NO}_{3}$ and phosphorus $(\mathrm{P})$ in the forms of phosphates $\mathrm{PO}_{4}$ [54]. In a study by Emerenciano et al. [12], low concentrations of $\mathrm{PO}_{4}$ (1.1-1.3 ppm) were recorded for pink shrimp $\mathrm{PL}_{25}$ reared in BFT and clear water systems for 30 days with a salinity of 35 ppt and fed commercial feed (40\% protein) twice a day. These concentrations are lower compared to those concentrations (8-38 ppm) reported by Durigon et al. [35] for Nile tilapia juveniles reared in the BFT system for 42 days with a salinity of $10 \mathrm{ppt}$ (similar to our salinity) and fed three levels of digestive protein (22, 26 and 30\%) and energy (3000, 3150 and $3300 \mathrm{Kcal} / \mathrm{kg}$ ) three times per day. As uneaten feed is the major source of $\mathrm{N}$ and $\mathrm{P}$ in aquaculture, formulated diets and feeding rates could affect levels of $\mathrm{PO}_{4}$ in culture water [55]. According to the present study, fingerlings of tilapia fish were reared in the recirculating system for 57 days at a salinity of 10 ppt and fed experimental diets with protein percentages from $25.75 \%$ to $33.34 \%$ three times per day. The results showed concentrations of $\mathrm{PO}_{4}(1.8-12.9 \mathrm{ppm})$ were within those concentrations found by previous studies [12,35]. However, T3 and T5 treatments (fed 16\% dried bioflocs) had higher uneaten feed weights and $\mathrm{PO}_{4}$ concentrations than $\mathrm{T} 1$ (the control), T2, and T4 treatments (fed $4 \%$ dried bioflocs). Consequently, the increase in $\mathrm{PO}_{4}$ can be linked and explained by the increase of the uneaten feed in the culture tanks. Thus, the high levels of $\mathrm{PO}_{4}$ may be due to the decrease in experimental feed consumption for treatments fed $16 \%$ dried bioflocs in the present study. Therefore, the management of excessive nutrients should be approached through diet formulation or feeding strategies [55]. However, $\mathrm{PO}_{4}$ can be monitored and removed periodically from culture water using phosphate test kits that are available, but as no active control is required, phosphate monitoring follows no set schedule, although it becomes more important when water is used to raise successive crops [45].

Despite the dried bioflocs used as supplements in the formulation of the experimental diets resulting in lower quality cultured water for red hybrid tilapia compared to the control in terms of T, DO, $\mathrm{pH}, \mathrm{EC}$, TDS, TAN, $\mathrm{NO}_{3}-\mathrm{N}$, these parameters were still within the range of standard levels for red hybrid tilapia culture $[25,40]$.

In the present study, the higher BOD and COD levels for T3 and T4 treatments resulted in lower DO levels for the same treatments. Similar results were found by Abdul Aziz et al. [56] who reported that the increase in BOD and COD indicated higher organic matter in the water which reduce the level of DO. However, the BOD (1.96-5.22 ppm) for all 
treatments in the present study were lower than those levels recorded by Menaga et al. [57] and Zaki et al. [58] for Nile tilapia (Oreochromis niloticus) reared in biofloc systems (6.30-6.85 and 18.15-27.88 ppm, respectively).

The high levels of COD in our study might be due to the salinity. Notably, when we compared the present results of water quality to results from an external freshwater tank of red hybrid tilapia (unpublished data), we observed that concentrations of COD in the culture tanks from the present study, when pure marine salt was added to adjust the salinity around $10 \mathrm{ppt}$, were higher than those concentrations from the external fresh water tank. For this reason, the increase in the concentrations of COD in the present study might be due to the salinity of $10 \mathrm{ppt}$.

It is very important to notice that the values of growth indicators from the present study showed an increasing trend when decreasing the supplement ratio of bioflocs (4\% dried bioflocs). Similar evidence was provided by Gamboa-Delgado et al. [59] who used bioflocs meal from tilapia source as a protein source for L. vannamei at different ratios $(25 \%, 50 \%$, and $75 \%)$ and observed a negative correlation between the inclusion ratio of bioflocs meal and weight gain of shrimp. Meanwhile values of water quality showed a decreasing trend with decreasing supplement ratio of bioflocs. From this point of view, the low \% SR for T3 and T5 treatments can be linked with the poor quality of water inside tanks of these treatments over the period of the experiment. The uneaten feed can affect the properties of water, which can result in poor quality of culture water and can lead to high mortality of fish [45]. In the present study, the increase in supplement ratio of bioflocs (at 16\% dried bioflocs) for T3 and T5 treatments resulted in higher uneaten feed weights, consequently, lower FI rates for these treatments. As a result of this, lower growth and survival rate, as well as poor water quality, were noticed for these treatments compared with the other treatments in the present study.

Proximate analyses of bioflocs showed different values for protein, lipid, and total nitrogen-free extraction (NFE) contents between the two drying methods (freeze-drying and oven-drying). Nutritionally, protein is the most important and expensive ingredient in formulated diets for culture animals [60]. Dried bioflocs produced by the freeze-drying method showed superior protein content compared to dried bioflocs produced by the oven-drying method in the present study. In other words, the protein content in bioflocs can be influenced by the drying methods, and the freeze-drying method in the present study positively affected the protein content in bioflocs. This has been supported recently by Binalshikh-Abubkr et al. [61] who found that freeze-dried bioflocs had higher protein content ( $24 \mathrm{~g} / 100 \mathrm{~g})$ than oven-dried bioflocs $(20 \mathrm{~g} / 100 \mathrm{~g})$. Although those values were lower than the present study ( 26 and $30.5 \mathrm{~g} / 100 \mathrm{~g}$ ) for protein contents, these values met the requirement of protein (20-50 g/100 g) for aquaculture species [62]. Moreover, bioflocs are considered good quality sources of protein that can be used as a feed for tilapia and provide about $50 \%$ of its protein requirement $[63,64]$. Even though the possibility of using bioflocs meal as an alternative source of animal protein source, protein from bioflocs should only be used as a supplementation for dietary proteins [16]. The positive effect of the freeze-drying method on protein content in bioflocs may be due to the benefit of using a freeze-dryer to dry sensitive microbial samples without lessening their protein content [65].

In contrast, the crud lipid content was higher in dried bioflocs produced by the oven-drying method. As a matter of fact, the lipid is usually low in dried bioflocs and ranged from $0.1-2.5[1,12,30,35,61,64,66,67]$. By the same token, values of crude lipid contents in bioflocs from the present study were low and fell in that range. In addition, total NFE contents were significantly affected by the drying methods, nevertheless, these contents (2.92-9.48 g/100 g) were lower compared to contents (16.45-29.40 g/100 g) found by many researchers $[12,13,30,61]$. Due to their low cost and energy, carbohydrates are typically included in fish diets at levels of $20-45 \mathrm{~g} / 100 \mathrm{~g}$, however, there is no specific dietary requirement for carbohydrates [68]. If dried bioflocs are used as a supplement to commercial fish feed, then there is no need for high levels of lipid or carbohydrate percentages in its proximate composition since enough amount of these percentages would 
be included in feed by the manufacturer. From this point of view, the freeze-drying method can be the appropriate drying method to produce bioflocs meal with higher protein content than the oven-drying method.

While proximate of experimental diets indicated that the $4 \%$ dried bioflocs diets (T2 and T4 treatments) showed protein and crude fiber contents similar to the control, while higher protein and lipid contents than the 16\% dried bioflocs diets (T3 and T5 treatments). However, lipid contents in all bioflocs diets were lower compared to the control diet. The decrease in lipid contents especially for $16 \%$ dried bioflocs diets in the present study can be explained by the low level of lipid in bioflocs composition [64]. Subsequently, the decrease in nutritional values of bioflocs diets may be due to the increase of supplemented bioflocs at a ratio of $16 \%$. In that case, therefore, supplementations at $4 \%$ dried bioflocs produced by freeze-drying or oven-drying methods can provide good quality of diets in terms of their nutritional value.

When comparing the final fish body compositions for the five treatments in the present study with the initial fish body composition, we found that fish fed $100 \%$ commercial feed (without bioflocs) resulted in a better quality of the final product (in terms of nutritional value) followed by fish fed $4 \%$ oven-dried or freeze-dried bioflocs. On the other hand, fish fed $16 \%$ oven-dried or freeze-dried bioflocs had lower quality of proximate in the present study. However, the proximate composition of the final product of tilapia (whole-body) from previous studies of feeding trials demonstrated moisture, protein, lipid, and ash contents ranged from 66.30-81.90, 10.90-19.33, 1.43-9.30, and 1.34-7.5 g/100 g, respectively $[31,32,34,69-72]$. Our values for final fish body composition were within those ranges from previous studies.

Overall, the comparison among the five experimental treatments (T1, T2, T3, T4, and $\mathrm{T} 5$ treatments) at the end of the experiment, indicated that $\mathrm{T} 1, \mathrm{~T} 2$ and $\mathrm{T} 4$ treatments ( $100 \%$ commercial feed, $4 \%$ freeze-dried bioflocs diet, and $4 \%$ oven-dried bioflocs diet, respectively) showed the best values of growth indicators, water quality parameters, and fish body composition. The T3 treatment ( $16 \%$ freeze-dried bioflocs diet) showed the poorest growth performance, water quality, and fish body composition, followed by $\mathrm{T} 5$ treatment ( $16 \%$ oven-dried bioflocs diet) in the present study. Thereupon, $4 \%$ freeze-dried bioflocs diet could be efficient for the growth performance of red hybrid tilapia, while $4 \%$ oven-dried bioflocs diet could be low-cost and efficient to control water quality parameters in red hybrid tilapia tanks.

\section{Conclusions}

Our results showed that a ratio of $4 \%$ freeze-dried and/or oven-dried bioflocs provided higher growth rates similar to the control (100\% commercial feed), while the ratio of $16 \%$ freeze-dried and/or oven-dried bioflocs showed a loss in growth rate for tilapia. Furthermore, the ratio of $4 \%$ dried bioflocs showed better water quality parameters compared to the ratio of $16 \%$ used in the present study. Based on these results, it is possible to include $4 \%$ freeze-dried or oven-dried bioflocs in formulated diets for red hybrid tilapia without losses on growth performance and water quality. This conclusion was also supported by optimum body compositions of tilapia fed of $4 \%$ dried bioflocs diets, which resulted in higher nutritional composition than tilapia fed of $16 \%$ dried bioflocs diets. Protein contents were significantly different between the two ratios of dried bioflocs. In addition, gross energy levels showed a decreasing trend with increasing supplement levels of bioflocs. Therefore, dried bioflocs produced by freeze-drying and/or oven-drying can be used successively as a dietary supplement at a ratio of $4 \%$ without any effect on growth performance, water quality, or body composition for red hybrid tilapia when reared in 10 ppt salinity.

Author Contributions: Formal analysis, T.B.-A.; writing — original draft preparation, T.B.-A.; writingreview and editing, M.M.H.; supervision, M.M.H.; project administration, M.M.H.; funding acquisition, M.M.H. All authors have read and agreed to the published version of the manuscript.

Funding: Marlia M. Hanafiah was financed by the UKM research grants (DIP-2019-001 and GUP-2020-034). 
Institutional Review Board Statement: Not applicable.

Informed Consent Statement: Not applicable.

Data Availability Statement: Data is contained within the article.

Acknowledgments: The authors would like to thank the Faculty of Science and Technology, UKM for providing laboratory services and facilities to conduct this research.

Conflicts of Interest: The authors declare no conflict of interest.

\section{References}

1. Kuhn, D.D.; Boardman, G.D.; Lawrence, A.L.; Marsh, L.; Flick, G. Microbial floc meal as a replacement ingredient for fish meal and soybean protein in shrimp feed. Aquaculture 2009, 296, 51-57. [CrossRef]

2. Merican, Z.; Sanchez, D. 2016 Overview of the aquaculture feed industry. In Aquafeed Formulation; Nates, S.F., Ed.; Academic Press, Elsevier Inc.: London, UK, 2015; pp. 1-19. [CrossRef]

3. Yun, H.; Shahkar, E.; Hamidoghli, A.; Lee, S.; Won, S.; Bai, S.C. Evaluation of dietary soybean meal as fish meal replacer for juvenile whiteleg shrimp, Litopenaeus vannamei reared in biofloc system. Int. Aquat. Res. 2017, 9, 11-24. [CrossRef]

4. Himaja, P.H.; Rajagopalasamy, C.B.T. Review on biofloc meal as an alternative ingredient in aquaculture feeds. J. Aquac. Trop. 2016, 31, 199-220.

5. Neto, J.R.S.; Ribeiro, F.A.S.; Gonçalves, A.A.; Emerenciano, M.G.C. Tilapia processing waste silage (TPWS): An alternative ingredient for Litopenaeus vannamei (Boone, 1931) diets in biofloc and clear-water systems. Aquac. Fish. 2019, 4, 214-218. [CrossRef]

6. Hende, S.F.D.; Claessens, L.; Muylder, E.D.; Boom, N.; Vervaeren, H. Microbial bacterial flocs originating from aquaculture wastewater treatment as diet ingredient for Litopenaeus vannamei (Boone). Aquac. Res. 2014, 47, 1075-1089. [CrossRef]

7. Martínez-Córdova, L.R.; Martínez-Porchas, M.; Emerenciano, M.G.C.; Miranda-Baeza, A.; Gollas-Galva'n, T. From microbes to fish the next revolution in food production. Crit. Rev. Biotechnol. 2016, 37, 287-295. [CrossRef] [PubMed]

8. Martinez-Porchas, M.; Vargas-Albores, F. Microbial metagenomics in aquaculture: A potential tool for a deeper insight into the activity. Rev. Aquac. 2017, 9, 42-56. [CrossRef]

9. Pikaar, I.; Matassa, S.; Rabaey, K.; Bodirsk, B.L.; Popp, A.; Herrero, M.; Verstraete, W. Microbes and the Next Nitrogen Revolution. Environ. Sci. Technol. 2017, 51, 7297-7303. [CrossRef]

10. D'Abramo, L.R.; Silva, J.L.; Kim, T. Optimization of crustacean quality through husbandry and adherence to post-harvest standards for processing. In Shellfish Safety and Quality; Shumway, S.E., Rodrick, G.E., Eds.; Woodhead Publishing: Cambridge, UK, 2009; Volume 167, pp. 339-358. [CrossRef]

11. Azim, M.E.; Little, D.C.; Bron, J.E. Microbial protein production in activated suspension tanks manipulating the C:N ratio in feed and the implications for fish culture. Bioresour. Technol. 2008, 99, 3590-3599. [CrossRef] [PubMed]

12. Emerenciano, M.; Ballester, E.L.C.; Cavalli, R.O.; Wasielesky, W. Biofloc technology application as a food source in a limited water exchange nursery system for pink shrimp Farfantepenaeus brasiliensis (Latreille, 1817). Aquac. Res. 2012, 43, 447-457. [CrossRef]

13. Shyne Anand, P.S.; Kohli, M.P.S.; Kumar, S.; Sundaray, J.K.; Roy, S.D.; Venkateshwarlu, G.; Sinha, A.; Pailan, G.H. Effect of dietary supplementation of biofloc on growth performance and digestive enzyme activities in Penaeus monodon. Aquaculture 2014, 418-419, 108-115. [CrossRef]

14. Khatoon, H.; Banerjee, S.; Yuan, G.T.G.; Haris, N.; Ikhwanuddin, M.; Ambak, M.A.; Endut, A. Biofloc as a potential natural feed for shrimp postlarvae. Int. Biodeterior. Biodegrad. 2016, 113, 304-309. [CrossRef]

15. Lee, C.; Kim, S.; Lim, S.; Lee, K. Supplemental effects of biofloc powder on growth performance, innate immunity, and disease resistance of Pacific white shrimp Litopenaeus vannamei. Fish. Aquat. Sci. 2017, 20, 15.1-15.7. [CrossRef]

16. Mahanand, S.S.; Pandey, P.K. Application of biofloc technology for sustainable aquaculture development. In Advances in Fish Research; Mohanty, B.P., Ed.; Narendra Publishing House: Delhi, India, 2019; Volume VII, pp. 263-274.

17. Dauda, A.B. Biofloc technology: A review on the microbial interactions, operational parameters and implications to disease and health management of cultured aquatic animals. Rev. Aquac. 2020, 12, 1193-1210. [CrossRef]

18. Kasan, N.A.; Ghazali, N.A.; Ikhwanuddin, M.; Ibrahim, Z. Isolation of potential bacteria as inoculum for biofloc formation in pacific whiteleg shrimp litopenaeus vannamei culture ponds. Pak. J. Biol. Sci. 2017, 20, 306-313. [CrossRef]

19. De Schryver, P.; Crab, R.; Defoirdt, T.; Boon, N.; Verstraete, W. The basics of bio-flocs technology: The added value for aquaculture. Aquaculture 2008, 277, 125-137. [CrossRef]

20. Walker, D.A.U.; Suazo, M.C.M.; Emerenciano, M.G.C. Biofloc technology: Principles focused on potential species and the case study of Chilean river shrimp Cryphiops caementarius. Rev. Aquac. 2020, 12, 1759-1782. [CrossRef]

21. Crab, R.; Defoirdt, T.; Bossier, P.; Verstraete, W. Biofloc technology in aquaculture: Beneficial and future challenges. Aquaculture 2012, 356-357, 351-356. [CrossRef]

22. Caldini, N.N.; Cavalcante, D.H.; Filho, P.R.N.R.; Sá, M.V.C. Feeding Nile tilapia with artificial diets and dried bioflocs biomass. Anim. Sci. Mar. 2015, 37, 335-341. [CrossRef]

23. Yue, G.H.; Lin, H.R.; Li, J.L. Tilapia is the fish for next-generation aquaculture. Int. J. Mar. Sci. Ocean Technol. 2016, 3, 11-13. [CrossRef] 
24. El-Sayed, A.M. Tilapia Culture, 2nd ed.; Academic Press, Elsevier Inc.: London, UK, 2020; 348p. [CrossRef]

25. Putra, I.; Effendi, I.; Lukistyowati, I.; Tang, U. Growth and survival rate of red tilapia (Oreochromis sp.) cultivated in the brackish water tank under biofloc system. Adv. Eng. Res. 2019, 190, 96-99. [CrossRef]

26. FAO. The State of World Fisheries and Aquaculture 2020. Sustainability in Action; Food and Agriculture Organization: Rome, Italy, 2020; p. 244. [CrossRef]

27. Thorarensen, H.; Kubiriza, G.K.; Imsland, A.K. Experimental design and statistical analyses of fish growth studies. Aquaculture 2015, 448, 483-490. [CrossRef]

28. Ariffin, F.D.; Halim, A.A.; Hanafiah, M.M.; Awang, N.; Othman, M.S.; Azman, S.A.A.; Bakri, N.S.M. The effects of African catfish, Clarias gariepinus pond farm's effluent on water quality of Kesang river in Malacca, Malaysia. Appl. Ecol. Environ. Res. 2019, 17, 1531-1545. [CrossRef]

29. Hanafiah, M.M.; Leuven, R.S.E.W.; Sommerwerk, N.; Tockner, K.; Huijbregts, M.A.J. Including the Introduction of Exotic Species in Life Cycle Impact Assessment: The Case of Inland Shipping. Environ. Sci. Technol. 2013, 47, 13934-13940. [CrossRef]

30. Kuhn, D.D.; Lawrence, A.L.; Crockett, J.; Marsh, L.; Taylor, D. Evaluation of biflocs derived from confectionary food effluent water as a replacement feed ingredient for fishmeal or soy meal for shrimp. Aquaculture 2016, 454, 66-71. [CrossRef]

31. Chowdhury, M.A.K.; Bureau, D.P. Predicting body composition of Nile tilapia (Oreochromis niloticus). Asian Fish. Sci. 2009, 22, 597-605. [CrossRef]

32. Takeuchi, T.; Lu, J.; Yoshizaki, G.; Satoh, S. Effect on the growth and body composition of juvenile tilapia Oreochromis niloticus fed raw Spirulina. Fish. Sci. 2002, 68, 34-40. [CrossRef]

33. Buyukcapar, H.M.; Atalay, A.I.; Kamalak, A. Growth performance of Nile tilapia (Oreochromis niloticus) fed with diets containing different level of hydrolysable and condensed tannin. J. Agric. Sci. Technol. 2011, 13, 1045-1051.

34. Silva, T.S.; Piana, P.A. Production of tilapia in biofloc with different salt condictions: An evaluation of body composition and organoleptic properties. Bol. Inst. Pesca 2020, 46, 605-615. [CrossRef]

35. Durigon, E.G.; Lazzari, R.; Uczay, J.; Lopes, D.L.A.; Jeronimo, G.T.; Sgnaulin, T.; Emerenciano, M.G.C. Biofloc technology (BFT): Adjusting the levels of digestible protein and digestible energy in diets of Nile tilapia juveniles raised in brackish water. Aquac. Fish. 2020, 5, 42-51. [CrossRef]

36. Lopez-Betancur, D.; Moreno, I.; Guerrero-Mendez, C.; Gomez-Melendez, D.; Macias, M.J.; Olvera-Olvera, C. Effects of colored light on growth and nutritional composition of tilapia, and biofloc as a food source. Appl. Sci. 2020, 10, 362. [CrossRef]

37. Emerenciano, M.; Gaxiola, G.; Cuzon, G. Biofloc technology (BFT): A review for aquaculture application and animal food industry. In Biomass Now-Cultivation and Utilization; Matovic, M.D., Ed.; IntechOpen: London, UK, 2013; pp. 301-328. [CrossRef]

38. Bossier, P.; Ekasari, J. Biofloc technology application in aquaculture to support sustainable development goals. Microb. Biotechnol. 2017, 10, 1012-1016. [CrossRef]

39. Correa, A.S.; Pinho, S.M.; Molinari, D.; Pereira, K.R.; Gutierrez, S.M.; Monroy-Dosta, M.; Emerenciano, M. Rearing of tilapia (Oreochromis niloticus) juveniles in a biofloc system employing periods of feed deprivation. J. Appl. Aquac. 2020, 32, 139-156. [CrossRef]

40. Pradeep, P.J.; Srijaya, T.C.; Hassan, A.; Chatterji, A.K.; Raghavan, R.; Withyachumnarnkul, B.; Jeffs, A. Growth performance of triploid red tilapia reared under laboratory conditions. J. Appl. Aquac. 2013, 25, 176-189. [CrossRef]

41. De Alvarenga, E.R.; Alves, G.F.O.; Fernandes, A.F.A.; Costa, G.R.; da Silva, M.A.; Teixeira, E.A.; Turra, E.M. Moderate salinities enhance growth performance of Nile tilapia (Oreochromis niloticus) fingerlings in the biofloc system. Aquac. Res. 2018, 49, 2919-2926. [CrossRef]

42. APHA. Standard Methods for the Examination of the Water and Wastewater, 21st ed.; American Public Health Association: Washington, DC, USA, 2005; 1220p.

43. Nizam, N.U.M.; Hanafiah, M.M.; Noor, I.M.; Karim, H.I.A. Efficiency of five selected aquatic plants in phytoremediation of aquaculture wastewater. Appl. Sci. 2020, 10, 2712. [CrossRef]

44. AOAC. Official Methods of Analysis, 16th ed.; Association of Official Analytical Chemists: Washington, DC, USA, 2016 ; p. 3172.

45. Prangnell, D.I.; Lupatsch, I.; Treece, G.D.; Samocha, T.M. 2019 Water Quality Management. In Sustainable Biofloc Systems for Marine Shrimp; Samocha, T.M., Ed.; Academic Press, Elsevier Inc.: London, UK, 2019; pp. 19-27. [CrossRef]

46. Helland, S.J.; Grisdale-Helland, B.; Nerland, S. A simple method for the measurement of daily feed intake of groups of fish in tanks. Aquaculture 1996, 139, 157-163. [CrossRef]

47. Summerfelt, R.C. Water quality considerations for aquaculture. Aquac. Netw. Inf. Cent. 1998, 50, 11-21.

48. Hargreaves, J.A.; Tucker, C.S. Managing ammonia in fish ponds. South. Reg. Aquac. Cent. 2004, 4603.

49. Hayashi, M. Temperature-electrical conductivity relation of water for environmental monitoring and geophysical data inversion. Environ. Monit. Assess. 2004, 96, 119-128. [CrossRef]

50. Manikam, M.K.; Halim, A.A.; Hanafiah, M.M.; Krishnamoorthy, R.R. Removal of ammonia nitrogen, nitrate, phosphorus and COD from sewage wastewater using palm oil boiler ash composite adsorbent. Desalination Water Treat. 2019, 149, 23-30. [CrossRef]

51. Robles-Porchas, G.R.; Gollas-Galvan, T.; Martinez-Porchas, M.; Martinez-Cordova, L.R.; Miranda-Baeza, A.; Vargas-Albores, F. The nitrification process for nitrogen removal in biofloc system aquaculture. Rev. Aquac. 2020, 12, 2228-2249. [CrossRef]

52. Soler-Jofra, A.; Pérez, J.; van Loosdrecht, M.C.M. Hydroxylamine and the nitrogen cycle: A review. Water Res. 2021, 190, 116723. [CrossRef] 
53. Long, L.; Yang, J.; Li, Y.; Guan, C.; Wu, F. Effect of biofloc technology on growth, digestive enzyme activity, hematology, and immune response of genetically improved farmed tilapia (Oreochromis niloticus). Aquaculture 2015, 448, 135-141. [CrossRef]

54. Araújo-Silva, S.L.; Moraes, M.A.B.; Carmo, C.F.; Osti, J.A.S.; Vaz-dos-Santos, A.M.; Mercante, C.T.J. Effluent of a polyculture system (tilapias and shrimps): Assessment by mass balance of nitrogen and phosphorus. J. Environ. Prot. 2014, 5, 799-804. [CrossRef]

55. Amirkolaie, A.K. Reduction in the environmental impact of waste discharged by fish farms through feed and feeding. Rev. Aquac. 2011, 3, 19-26. [CrossRef]

56. Abdul Aziz, N.I.H.; Hanafiah, M.M.; Halim, N.H.; Fidri, P.A.S. Phytoremediation of TSS, $\mathrm{NH}_{3}-\mathrm{N}$ and COD from sewage wastewater by Lemna minor L., Salvinia minima, Ipomea aquatica and Centella asiatica. Appl. Sci. 2020, 10, 5397. [CrossRef]

57. Menaga, M.; Felix, S.; Charulatha, M.; Gopalakannan, A.; Panigrahi, A. Effect of in-situ and ex-situ biofloc on immune response of Genetically Improved Farmed Tilapia. Fish Shellfish. Immunol. 2019, 92, 698-705. [CrossRef] [PubMed]

58. Zakia, M.A.A.; Alabssawy, A.N.; Nour, A.M.; Basuini, M.F.; Dawood, M.A.O.; Alkahtani, S.; Abdel-Daim, M.M. The impact of stocking density and dietary carbon sources on the growth, oxidative status and stress markers of Nile tilapia (Oreochromis niloticus) reared under biofloc conditions. Aquac. Rep. 2020, 16, 100282. [CrossRef]

59. Gamboa-Delgado, J.; de Oca, G.A.R.M.; Reyes, J.C.R.; Villarreal-Cavazos, D.A.; Nieto-Lopez, M.; Cruz-Suarez, L.E. Assessment of the relative contribution of dietary nitrogen from fish meal and biofloc meal to the growth of Pacific white shrimp (Litopenaeus vannamei). Aquac. Res. 2017, 48, 2963-2972. [CrossRef]

60. Craig, S.; Helfrich, L.A.; Kuhn, D.D.; Schwarz, M.H. Understanding Fish Nutrition, Feeds, and Feeding; Publication Number 420-256; Virginia Cooperative Extension: Roanoke, VA, USA, 2017. Available online: https://vtechworks.lib.vt.edu/handle/10919/80712 (accessed on 24 February 2021).

61. Binalshikh-Abubkr, T.; Hanafiah, M.M.; Das, S.K. Proximate chemical composition of dried shrimp and tilapia waste bioflocs produced by two drying methods. J. Mar. Sci. Eng. 2021, 9, 193. [CrossRef]

62. FAO. The Nutrition and Feeding of Farmed Fish and Shrimp-A Training Manual; 1. The Essential Nutrients. Government Cooperative Programme; Tacon, A.G.J., Ed.; FAO/UNDP: Roma, Italy, 1987. Available online: http://www.fao.org/3/ab470e/AB470E00.htm\# TOC (accessed on 24 July 2021).

63. Avnimelech, Y. Feeding with microbial flocs by tilapia in minimal discharge bio-flocs technology ponds. Aquaculture 2007, 264, 140-147. [CrossRef]

64. Azim, M.E.; Little, D.C. The biofloc technology (BFT) in indoor tanks: Water quality, biofloc composition, and growth and welfare of Nile tilapia (Oreochromis niloticus). Aquaculture 2008, 283, 29-35. [CrossRef]

65. Berk, Z. Freeze drying (lyophilization) and freeze concentration. In Food Process Engineering and Technology, 3rd ed.; Berk, Z., Ed.; Academic Press, Elsevier Inc.: London, UK, 2018; pp. 567-581. [CrossRef]

66. Bauer, W.; Prentice-Hernandez, C.; Tesser, M.B.; Wasielesky, W., Jr.; Poersch, L.H.S. Substitution of fishmeal with microbial floc meal and soy protein concentrate in diets for the pacific white shrimp Litopenaeus vannamei. Aquaculture 2012, 342-343, 112-116. [CrossRef]

67. Avnimelech, Y. Biofloc Technology—A Practical Guide Book, 2nd ed.; The World Aquaculture Society: Baton Rouge, LA, USA, 2015; 268p.

68. Lall, S.P.; Dumas, A. Nutritional requirements of cultured fish: Formulating nutritionally adequate feeds. In Feed and Feeding Practices in Aquaculture; Davis, D.A., Ed.; Woodhead Publishing Series in Food Science; Technology and Nutrition: Cambridge, UK, 2015; pp. 53-109. [CrossRef]

69. Younis, E.M.; Al-Quffail, A.S.; Al-Asgah, N.A.; Abdel-Warith, A.A.; Al-Hafedh, Y.S. Effect of dietary fish meal replacement by red algae, Gracilaria arcuata, on growth performance and body composition of Nile tilapia Oreochromis niloticus. Saudi J. Biol. Sci. 2018, 25, 198-203. [CrossRef] [PubMed]

70. Gallardo-Collı' , A.; Pe'rez-Rostro, C.I.; Herna 'ndez-Vergara, M.P. Reuse of water from biofloc technology for intensive culture of Nile tilapia (Oreochromis niloticus): Effects on productive performance, organosomatic indices and body composition. Int. Aquat. Res. 2019, 11, 43-55. [CrossRef]

71. Mabroke, R.S.; El-Husseiny, O.M.; Zidan, A.F.A.; Tahoun, A.; Suloma, A. Floc meal as potential substitute for soybean meal in tilapia diets under biofloc system conditions. J. Oceanol. Limnol. 2019, 37, 313-320. [CrossRef]

72. Da Silva, M.A.; de Alvarenga, E.R.; da Costa, F.F.B.; Turra, E.M.; Alves, G.F.O.; Manduca, L.G.; Sales, S.C.M.; Leite, N.R.; Bezerra, V.M.; Moraes, S.G.S.; et al. Feeding management strategies to optimize the use of suspended feed for Nile tilapia (Oreochromis niloticus) cultivated in bioflocs. Aquac. Res. 2020, 51, 605-615. [CrossRef] 